\title{
What Are Warlike Operations Under F. C. \& S. Clause in Marine Policies
}

\section{S. Hasket Derby*}

$T_{\text {policies reads as follows: }}^{1}$ He capture and seizure) clause in marine

"Warranted free of capture, seizure, arrest, restraint, or detainment, and the consequences thereof or of any attempt thereat (piracy excepted), and also from all consequences of hostilities or war-like operations whether before or after declaration of war."

There have been many decisions under this clause by the English courts and three decisions by American courts and they cannot all be reconciled.

Two of the most famous of the English cases are those of The Petersham ${ }^{2}$ and The Matiana. ${ }^{3}$ In The Petersham, a merchant vessel under charter to the British Admitalty, was carrying a cargo of iron ore from Bilboa to Glasgow and, while sailing without lights as ordered by the Admiralty, she collided with a Spanish vessel and was sunk. There was no showing for what purpose the iron ore was intended to be used nor was there any evidence that any hostile vessel was in the neighborhood. The House of Lords held that the loss of the vessel could not be attributed to "hostilities" or "warlike operation." In The Matiana, the vessel was proceeding from Alexandria to a British port with a cargo of cotton and was forced to sail without lights under convoy. While the convoy was traversing a part of the Mediterranean usually infested by submarines and steering under orders of the officer in charge of the convoy a course more northerly than that adopted in times of peace, she was lost by stranding on a reef (though she was in fact torpedoed later). The House of Lords held, two judges out of five dissenting, that the Matiana was not lost as a result of warlike operations. It should be carefully noted, how-

*A.B., Harvard, 1899; LL.B., 1902. Member of San Francisco Bar.

1 EldRmge, Marine Poticnes (3d ed. 1938) 282.

2 Britain S. S. Co. v. The King [1921] 1 A.C. 99, 15 Asp. M.C. 58.

3 Greèn v. British Indiana Steam Navigation Co. et al., ibid. 
ever, that both vessels were proceeding on peaceful missions between ports which were not war bases and that the cargoes were purely commercial and not contraband. Lord Wrenbury aptly sums up the results of the two cases as follows:

"To apply these principles to the two cases before the House: The Petersham was lost by collision by reason of navigation in the dark without hights. The risk of collision at night is an ordinary maritime risk. It was aggravated by the removal of the protection of the usual lights of navigation. This is governed by the principle of Ionides, which I think was right, and which in fact counsel have not attacked. The Matiana was lost by going on a reef when sailing in convoy. To sail in convoy is to increase the every-day maritime risk of collision whether with a fixed object or with another vessel, for vessels in a convoy are necessarily not far apart. But there was no new risk. The abandonment of navigation lights in the case of the Petersham by way of protection against attack by submarine, the sailing in convoy in the case of the Matiana by way of protection against the like attack, are in principle similar. They are devices to give in time of war additional protection against an existing maritime risk. Their object is to give greater security to peaceful operations."

In the case of The Ionides, ${ }^{5}$ the earliest case on the subject, a vessel proceeding from New Orleans to New York during the Civil war went ashore south of Cape Hatteras, due to the fact that the confederate troops had extinguished the light there. It was held that she was lost by a marine peril and not by reason of hostilities. Here again the cargo was apparently neutral and the ship was engaged in a peaceful mission.

In Larchgrove v. The King ${ }^{6}$ a merchant vessel chartered to the United States Navy, carrying munitions for the American army in France, was held to be only a cargo ship.

In Harrisons Ltd. v. Shipping Controller the vessel stranded was a mechantman carrying a cargo of hospital stores for the British Government and a few British troops from Salonica to Taranto in Italy and ran ashore. The court held that the vessel was not engaged in a warlike operation, laying special stress on the fact that she was only a merchantman and not a vessel of war.

4 Supra note 2, at 136, 15 Asp. M.C. at 58.

5 Ionides v. The Universal Marine Ins. Ass'n (1863) 14 C.B. (N.s.) 259; 10 Juris. (N.S.) $18 ; 11$ W.R. 858.

(1919) 36 T.L.R. 108, 1 Il. L. Rep. 498.

7 [1921] 1 K.B. 122, 15 Asp. M.C. 270. 
In France, Fenwick \& Co. Ltd. v. North of England P. \& I. Association $^{8}$ a vessel was sunk by a German submarine and another vessel which ran on the wreck was held not damaged by a warlike operation.

The above are the principal English cases holding what are not warkike operations. Before examining the American cases, it would probably be well to discuss the English cases holding what are warlike operations, because, as said by Justice Holmes in the Queen Insurance Co. case, ${ }^{9}$ American courts should keep in harmony with the marine insurance law of England, "the great field of this business."

In The Geelong, ${ }^{10}$ a collision case, a vessel chartered by the Australian government was carrying a cargo of normal merchandise. The other vessel, a British merchant ship, was carrying military stores between British war bases. It was held that the collision was a result of warlike operations. It is submitted by the writer that it is difficult to reconcile this case with the Harrisons and Larchgrove cases, supra. In Attorney General v. Ard Coasters ${ }^{11}$ a merchant vessel, requisitioned by the government, was run into and sunk by a destroyer patrolling for submarines and it was held that the collision was due to warlike operations on the part of the destroyer. So, also, in Liverpool \& London War Risks Ins. Association, Ltd. v. Marine Underwriters of the S.S. Richard de Larrinaga ${ }^{12}$ the collision was between a merchant vessel and an armoured cruiser on her way to escort a convoy and it was held due to warlike operations on the part of the cruiser.

In Henry and MacGregor v. Marten ${ }^{13}$ a steamer encountered a semi-submerged object, which her captain took for an enemy submarine and rammed it, thus injuring his ship. It was held that the war risk underwriters were liable.

In Adelaide S.S. Co. v. The King (The Warilda), ${ }^{14}$ The Warilda, which was used as a hospital ship, but treated by the Australian Government, which chartered her, as an ambulance transport and was

8 [1917] 2 K.B. 522, 14 Asp. M.C. 92.

${ }^{9}$ Queen Insurance Co. v. Globe \& Rutgers Fire Ins. Co. (1923) 263 U.S. 487.

10 Peninsular and Oriental Branch Service v. Commonwealth Shipping Representative [1923] 1 A.C. 191, 15 Asp. M.C. 522.

11 [1921] 2 A.C. 141, 15 Asp. M.C. 353.

12 Ibid.

13 (1918) 34 T.L.R. 504.

14 [1923] A.C. 292, 16 Asp. M.C. 178. 
armed with a gun, came into collision with a merchant vessel. It was held that she was, under the Geelong decision, engaged in a warlike operation. The court also took occasion to hold that it made no difference whether the Warilda was negligent or not in determining this question. It should be pointed out, however, that, where the collision is entirely due to the fault of the vessel not engaged in a warlike operation the loss is not a consequence of the warlike operation. ${ }^{15}$ It should also be pointed out that the owners of the Warilda were only allowed to recover their own damages as due to war risk and could not recover the damages paid the other vessel. ${ }^{16}$

In Hain S.S. Co. v. Board of Trade (Trevanion Roanoke case) ${ }^{17}$ a British merchant ship carrying a cargo of oats, collided with an American mine planter which was returning to the United States after the armistice with a load of mines. It was held that the latter vessel was engaged in a warlike operation.

In Yorkshire Dale S.S. Co., Ltd. v. Minister of War Transport (The Coxwold), ${ }^{18}$ a convoyed vessel carrying military supplies from one war base to another stranded, and it was held that she was engaged in a warlike operation. Lord Simon, the Lord Chancellor, there presents an exhaustive summary of the English cases, showing that, since the decisions in The Petersham and The Matiana, the law has developed to a considerable extent, so that now it is no longer important that the vessel damaged is a merchant vessel and that such vessels if carrying war supplies are engaged in warlike operations and are on the same footing as war vessels.

Lord Porter in the same case presents a tabulation of precedents in British cases, which are well summarized as follows: ${ }^{19}$

"(1) In this as in every other insurance problem, the proximate cause is alone to be looked at. (Ionides vs. Universal Marine Ins. Co.)

"(2) But the proximate cause is not necessarily the nearest in point of time; it is the dominant cause. (Leyland S.S. Co. vs. Norwich Union Fire Ins. Co., and Samuel V. Dumas.)

"(3) In the case of a ship proceeding on a voyage which is not itself a warkike operation, absence of hights, sailing in convoy and zigzagg-

15 Clan Line Steamers v. Board of Trade [1929] A.C. 514, 17 Asp. M.C. 533;

Charente S.S. Co. v. Director of Transport (1921) 38 T.L.R. 148, 434.

16 [1926] A.C. 172, 16 Asp. M.C. 579.

15 [1929] A.C. 534, 17 Asp. M.C. 520 .

18 [1942] A.C. 691, 58 T.L.R. 263, [1942] A.M.C. 1000.

19 Ibid., [1942] A.M.C. at 1001, 1002. 
ing are not separately or in combination a warlike operation, nor, indeed, is it a warlike operation to follow the course set by the naval officer in charge of the convoy. (Petersham and Matiana.)

"(4) The dimming or extinguishing of a shore light is a warlike operation, but if a ship engaged in a mercantile operation goes ashore because she is out of her reckoning, she is not lost by the warlike operation merely because she would most probably have realized and avoided the danger had the hight been seen. (Ionides.)

"(5) A ship carrying war stores from one war base to another is engaged in a warlike operation. (Geelong.)

"(6) A collision caused by a ship so engaged is caused by the warlike operation. (Ardgantock and Richard de Larrinaga.)

"(7) A collision caused solely by a ship engaged on a mercantile adventure is not caused by a warhike operation even though the ship collides with or is struck by one engaged on a warlike operation. (Clan Matheson.)

"( 8 ) If the collision be caused both by the ship engaged and by one not so engaged so that both were effective causes of the disaster, the consequent loss is due to warlike operation. (Board of Trade vs. Hain S.S. Co.)

"(9) The collision if due in whole or in part to the action of the ship engaged in a warlike operation, does not cease to be caused by the warlike operation by reason of the fact that action is negligent." (Wasrilda.)"

The court distinguishes the Matiana case because the cargo in that case was cotton and because the vessel was not then proceeding between war bases, but it is apparent from reading the opinions that there is considerable doubt as to whether the case was rightly decided and only the fact that the House of Lords never reverses itself prevented the court from overruling it. This is apparent from the following language used by Lord Wright: ${ }^{20}$

"A more difficult problem was presented in Green v. British India Steam Navigation Company (The Matiana) reported along with Britain Steamship Company v. Rex (supra). The facts were up to a point practically identical with those of the present appeal. The crucial question there was whether the vessel was engaged on a warlike operation. The majority of their Lordships held that as regards the convoyed merchantmen, sailing without lights and in convoy and by an unusual route under naval orders did not constitute a warlike operation. That case is to be distinguished, according to the authorities to which I now refer, from the present case because of the

$20 \mathrm{Ibid}$. at 708, 58 T.L.R. at 267, [1942] A.M.C. at 1001 . 
nature of the cargo of The Matiana, which was cotton, and because neither her port of departure nor her port of arrival was a 'war base'."

In British \& Foreign S.S. Co. v. The King (St. Oswald case) ${ }^{21}$ a vessel was requisitioned by the Admiralty to go to Gallipoli and pick up troops there and, while on her way, collided with another vessel. It was held that she was engaged in a warlike operation.

There are other cases on this subject, but they involve situations where the war risk was or was not obvious and are not worth while discussing. ${ }^{22}$ The whole subject is exhaustively treated in II Arnould on Marine Insurance (12th ed.) Sections 905c-905f.

21 [1918] 2 K.B. 879, 14 Asp. M.C. 270.

22 Cases not cited in the foregoing article, where the nature of the risk was obvious:

Vessels missing, presumably in vicinity of submarines or mimes and loss held due to war risks: Oriole (1915) 31 T.L.R. 630; Membland (1916) 32 T.L.R. 581 ; Euterpe (1917) 33 T.L.R. 540; Ava (1917) 34 T.L.R. 140; Inveramsay [1920] 3 K.B. 94 ; General de Boisdeffre (1923) 14 Ll. L. Rep. 25; Albyn (1924) 18 L1. L. Rep. 98.

Vessels actually torpedoed or sunk by mines or bombs: Ikaria [1918] A.C. 350; El Zorro (1918) 34 T.L.R. 466; Tennyson (1918) 14 Asp. M.C. 430; Alice H. (1919) 14 Asp. M.C. 497.

Collision cases where one or both of the vessels were engaged in war duties: Caroline and Merida (1921) 7 Ll. L. Rep. 56; Maryland and Pacuare (1921) 9 Ll. L. Rep. 370; Instructor and America (1922) 10 Ll. L. Rep. 514; Kate and H. M. S. Marshford (1924) 18 LI. L. Rep. 152; San Gregorio \& Fernleaf (1925) 23 Ll. L. Rep. 301; Commonwealth Shipping Representative v. P.\& O. Branch Service [1923] A.C. 292.

Other war risk cases: Green v. Emslie (1795) 1 Peake N.P. 278 (capture after stranding on enemy coast); Livie v. Jansen (1810) 12 East 648 (sanue point) ; Anderson v. Marten [1908] A.C. 334, 10 Asp. M.C. 494 (vessel lost by sea perils after capture) ; Robinson Gold Mining Co. v. Alliance Ins. Co. [1902] 2 K.B. 489; Hindustan (1921) 37 T.L.R. 856 (damage by fire from spontaneous combustion of coal kept on board by order of naval authorities).

Marine risk cases: Hagedorn v. Whitmore (1816) 1 Starkie 157 (British vessel seized and towed by British man-of-war and cargo damaged by sea perils) ; Nickels v. London, etc. Ins. Co. (1900) 6 Com. Cas. 15 (vessel returning to loading port because of outbreak of war); Sherwood (1917) 14 Asp. M.C. 92 (collision with submerged wreck of torpedoed vessel); Pelayo, 23 Com. Cas. 264 (missing vessel and evidence of bad weather in vicinity of loss) ; Taikosan Morn \& Ancona, Lloyd's List Feb. 10, 1919 (collision of merchant vessels); Exmoor (1920) 4 Ll. L. Rep. 286 (stranding of merchant vessel on course altered to avoid mine); Admiralty Commissioners v. Brymawel S.S. Co. (1923) 17 Ll. L. Rep. 89 (colher bumping against mine sweeper while coabing her before she resumed warlike operations); W. I. Radcliffe \& Sylvan Arrow (1925) 23 Ll. L. Rep. 278 (collision between two merchant vessels requisitioned by British and American governnents, but not yet engaged in war duties) ; Brendonia \& Alderpool (1941) $70 \mathrm{Ll}$. L. Rep. 56 (collision hetween merchant vessel at anchor and one requisitioned, but not yet engaged in war duties) ; Clan Stuart \& Orlock Head (1942) 73 Ll. L. Rep. 165 (collision between two merchant vessels, one carrying steel billets for armament factories, the cargo, however, being held to be industrial). 
It is submitted that while the Petersham and Matiana cases are probably still law, the Larchgrove and Harrisons cases may be considered as overruled by the later cases, such as The Geelong and The Coxwold and further, that the rulings in the Petersham and Matiana cases, especially the latter, might not now be followed.

The net result of the British cases, therefore, seems to be:

1. That a merchant vessel proceeding on a peaceful voyage with an ordinary commercial cargo, even if in convoy, and sailing without lights, is not engaged in a warlike operation.

2. That a merchant vessel carrying any kind of war supplies for the government between war basis is engaged in a warlike operation. This principle applies to ships used as hospital ships.

3. That a warship engaged in performing her duties is almost always engaged in a warlike operation. (Per Atkin, L.J., in The Petersham case in the Court of Appeal. $)^{23}$ This, however, would probably not include a case where a warship was merely preparing to perform her duties, as, for instance, while being painted or drydocked. ${ }^{21}$

4. That in cases of convoys, a convoying vessel is performing a warlike operation, but the convoyed vessel engaged in an ordinary commercial voyage is not (The Matiana, supra).

5. That negligence or lack of negligence makes no difference, unless the collision, is solely caused by the vessel not engaged in war duties.

We should also consider the dates of the English decisions and the courts by which they are decided:

American cases: Patrick \& Brown v. Commercial Ins. Co. (1814) 11 Johns 10 (vessel stranded and then seized by French troops and burned. Held, a marine loss, as she was constructive total loss as stranded) ; Coolidge \& Oliver v. N. Y. Firemen Ins. Co. (1817) 14 Johns 307 (ship captured by British and then damaged. Held, a war loss.); Magoun v. New England Marine Ins. Co. (1840) Fed. Case No. 8961, 16 Fed. Cas., 1 Story 157 (schooner seized and became constructive total loss through deterioration); Dole v. New England Mutual Marine Ins. Co. (1864) Fed. Case No. 3966, 7 Fed. Cas., 2 Cliff 394 (ship taken and burned by Confederate privateer. Held, loss not covered by marine policy with f. c. \& s. clause.) ; Muller v. Glove \& Rutgers Fire Ins. Co. (1917) 246 Fed. 759 (Swedish steamer stranded while off her course under orders of British Naval Officer. Held, a war risk.) ; Standard Oil Co. of New Jersey v. U.S. (1925) 267 U.S. 76 (similar case).

23 Britain S. S. Co. v. The King [1919] 2 K.B. 670, 695, 14 Asp. M.C. 507, 512.

24 See Lord Wrenbury in Attorney General v. Ard Coasters [1921] 2 A.C. 141, 156, 15 Asp. M.C. 353, 357. 
CASES WHERE RISK HELD NOT A WAR RISK

$\begin{array}{lll}\text { CASE } & \text { DATE } & \text { COURT } \\ \text { Ionides } & 1863 & \text { Common Pleas } \\ \text { France, Fenwick \& Co. } & 1917 & \text { King's Bench } \\ \text { Larchgrove } & 1919 & \text { King's Bench } \\ \text { Petersham } & 1921 & \text { House of Lords } \\ \text { Matiana } & 1921 & \text { House of Lords } \\ \text { Harrisons } & 1921 & \text { King's Bench }\end{array}$

CASES WHERE RISK HELD A WAR RISK

$\begin{array}{lll}\text { Henry \& MacGregor } & 1918 & \text { King's Bench } \\ \text { St. Oswald } & 1918 & \text { Court of Appeal } \\ \text { Ardgantock } & 1921 & \text { Court of Appeal } \\ \text { Richard de Larrinaga } & 1921 & \text { Court of Appeal } \\ \text { Geelong } & 1923 & \text { Court of Appeal } \\ \text { Warrilda } & 1923 & \text { House of Lords } \\ \text { Trevanion-Roanoke } & 1929 & \text { Court of Appeal } \\ \text { Coxwold } & 1942 & \text { House of Lords }\end{array}$

It will thus be observed that six cases materially extending the meaning of the words "warlike operations" were decided after the Petersham and Matiana decisions and also after the Harrisons case. It should further be observed in this connection that the Morgan case $^{23}$ was decided in 1871 and the Queen Insurance Company case ${ }^{26}$ in 1923 (two American cases) and also that at the time of the latter decision the Geelong and Warrilda cases had only just been decided, while the Trevanion-Roanoke and Coxwold cases were far in the future. While the Geelong and Warrilda cases were referred to in the argument in the Queen Insurance Company case, Justice Holmes appears to have paid no attention to them and they were not reported at the time of the district court and circuit court of appeals decisions. The four cases referred to make important changes in the English law.

Let us now turn to the American authorities. In Morgan v. United States $^{27}$ a vessel was chartered by the government during the Civil war to transport troops and munitions of war and was ordered to sea

25 Morgan v. United States (1871) 81 U.S. 531.

20 Supra note 9.

n Supra note 25. 
by a quartermaster and was badly damaged by sea perils. It was held that the damage was not due to war risk. This holding is squarely opposed to the English decisions above mentioned, especially those in the Geelong, Warrilda, Trevanion-Roanoke and Coxwold cases heretofore mentioned.

In Queen Insurance Co. v. Globe \& Rutgers Fire Insurance Co ${ }^{28}$ the steamer Napoli sailed from New York to Genoa with a contraband cargo intended for the Italian government, part of which was munitions of war. She was sailing in convoy without lights under orders and collided in the Mediterranean with a British vessel also in convoy. The Court rests its decision that the Napoli was not engaged in a warlike operation partly on the Morgan case, but also on The Matiana, completely overlooking the fact that in The Matiana, the vessel was not proceeding between two war bases and that its cargo was neutral (see The Coxwold). It is submitted that this case also is opposed to the British cases, although Justice Holmes, speaking for the Court, expresses a strong desire to be in harmony with the English cases. Judge Hough, a jurist of great eminence, in giving judgment in the district court, expressed his personal view that a warlike operation was involved and only reached the contrary view with great reluctance. It has also been pointed out that most of the British cases heretofore cited had not yet been decided and the courts apparently only had before them the Ionides, Petersham, Matiana, Larchgrove and Harrisons cases. ${ }^{20}$ If the other cases had been con-

\footnotetext{
${ }^{28}$ Supra note 9. The reports of the case in the district court and the circuit court of appeals will be found in (1922) $278 \mathrm{Fed} .770$ and (1922) 282 Fed. 976.

29 See 282 Fed. 976, 980, 981. Judge Hough expresses his personal view as follows (278 Fed. 770, 781):

"The baldest statement of hibelant's position is to say that the act of sailing in convoy without lights is in and of itself a warkike operation; and from this flows the conclusion that such marine disasters as may reasonably be expected to result from convoy dangers are themselves the result of warlike operations. My own view on this matter is that of Bailhache, J., expressed in The Petersham, Britain, etc., Co. v. The King [1919] 1 K.B. 575 (580), and The Matiana, British, etc., Co. v. Green [1919] 1 K.B. 632 (636) viz.:

"'However peaceful the immediate business upon which a ship is engaged, if she is sailing as one of a convoy she is engaged, in my opinion, in a warbike operation. The assembling, presence, protection, and movements of the king's ships protecting the convoy are a warkike operation, and both convoyed and convoying ships are taking part in it, and that character attaches to the whole flotilla and covers the whole operation.'

"And the learned judge continues:

"'Suppose a dangerous route from which lights had been removed was prescribed (by the authorities) to deceive the enemy; and a ship taking sucb a route, without neg-
} 
sidered a different result would doubtless have been reached and it is submitted that, under the conformity principle, it is not now too late to overrule the decision in the Queen Insurance Company case. The Supreme Court followed this principle in reversing itself in a case involving Hawaiian law in order to conform to the changed views of the local court in Kapiolani Estate v. Atcherley. ${ }^{30}$ It should be all the more ready to do this in order to conform to the marine insurance law of England-"the great field of the business." The Supreme Court, unlike the House of Lords, does sometimes reverse its earlier decisions. $^{31}$

The last American case to be referred to is that of the Eastern Prince-Roustabout. . $^{32}$ There the Roustabout, a navy tanker, was proceeding between war bases on the west coast of the United States and Alaska, with a cargo of petroleum products for United States naval vessels and it was held, in a case where she negligently collided with a merchant vessel, that she was engaged in a warlike operation. The court said that the Queen Insurance Company case involved two principles-the first being to stop inquiry with the cause nearest the loss, and the second being to follow the English court decisions for the sake of expediency and harmony. The court said that the latter requirement was "a more specific and less variable criterion than that of stopping at the cause nearest to the loss" and hence felt that

ligence, runs ashore and is lost as the direct result of the removal of the lights; would such a loss be covered by the words 'warlike operation'? I think it would, but not because the ship was carrying out a warlike operation. The warlike operation would be the removal of the lights.'"

The same view is taken by Judge Mayer in the Circuit Court of Appeals (282 Fed. 976, 983):

"Thus impulse was given to the 'aggravated marine peril' theory. But I think it is going far to extend that theory to the case at bar. The theory of this case should be that 'a warlike operation' is not confined to actual offense, attack, or arined engagement, but may, in any event, coinprelıend a movement of vessels initiated in accordance with sovereign compulsion for the purpose of delivering inunitions and supplies either to one's own country or to allies or associates. Of course, extravagant or fanciful illustrations may be advanced to show the extremes to which such a theory may be carried, with, it is contended, illogical results; but illustrations of that character are rarely helpful. Yet, whatever our own views may be, I think the District Court, per Hough, J., was right in recognizing the commercial necessity of following the Petersham and Matiana cases, decided by the House of Lords by the narrow margin of three to two."

30 (1914) 238 U.S. 119.

31 See United States v. Darby (1940) 312 U.S. 100; West Coast Hotel Co. v. Parrish (1937) 300 U.S. 379.

39 (1944) 56 Fed. Supp. 275, [1944] A.M.C. 727. 
under the English decisions postdating the Queen Insurance Company decision it was free to disregard the latter.

Hence, despite the Supreme Court decisions, it is submitted that they are no longer good law and that they will, in due course, be overruled.

We have not considered in this article just what navy and army vessels can be considered as coming within the scope of being vessels engaged in warlike operations, because there are apparently no decisions on this subject. It is submitted, however, that any vessel engaged in assisting our war efforts falls within this category unless its activity is clearly not a part of the war effort. This would cover all supply ships, tugs and the like engaged in rendering aid to United States army and navy vessels performing war duties. 